\title{
MAURÍCIO PEREIRA
}

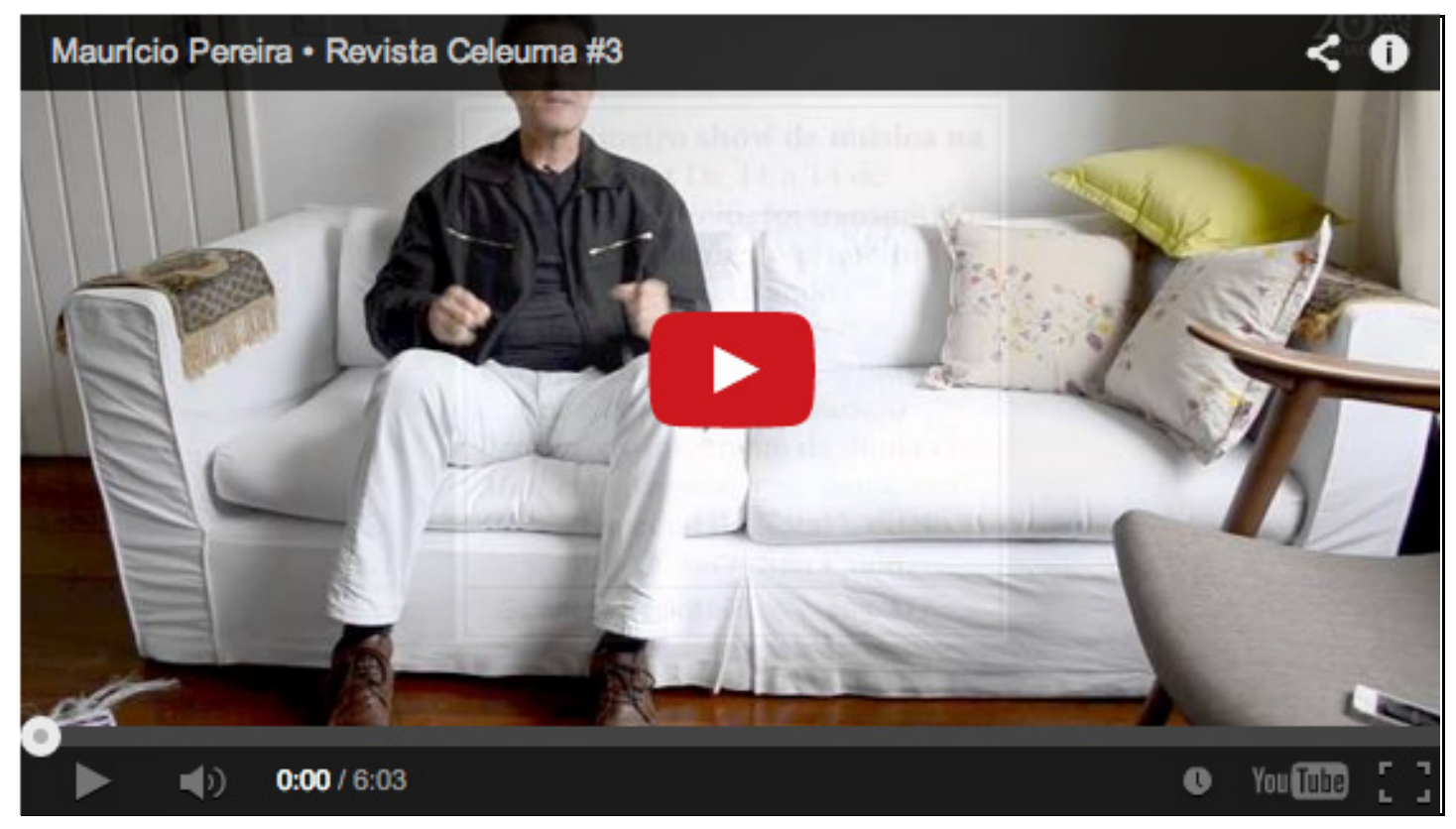

